\title{
Effects of peroral supplementation of different forms of zinc on the ruminal mucosa of goat kids - a morphometric study
}

\author{
Julius Černík ${ }^{1}$, Leoš Pavlata², Alena Pechováa ${ }^{3}$ Lubica Mišurováa ${ }^{2}$ Olga Jokverová2, \\ Jiří Luňáček ${ }^{4}$, Roman Halouzka ${ }^{1}$
}

\begin{abstract}
${ }^{1}$ University of Veterinary and Pharmaceutical Sciences Brno, Faculty of Veterinary Medicine, Department of Pathological Morphology and Parasitology, ${ }^{2}$ Ruminant and Swine Clinic, ${ }^{3}$ Faculty of Veterinary Hygiene and Ecology, Department of Biochemistry, Biophysics and Chemistry, Brno, Czech Republic ${ }^{4}$ Brno University of Technology, Faculty of Business and Management,

Department of Economy, Czech Republic
\end{abstract}

Received January 21, 2013

Accepted August 28, 2013

\begin{abstract}
The aim of the study was to identify the effect of supplementation of various forms of zinc on the ruminal mucosa and dimensions of ruminal papillae in 6-month-old goat kids. The experimental period lasted from weaning to slaughter (4 months). All 20 kids divided into four groups of five animals, were fed with the same feeding dose, which was different only in the quantity and form of zinc. Control group was without additional zinc supplementation (group A), the other groups were supplemented with zinc in the form of $\mathrm{ZnO}$ (group B), zinc in the form of chelate (group C) and zinc in the form of lactate (group D). Samples for histopathological and morphometric examination were collected after the slaughter of all animals from the bottom of saccus ruminis ventralis everytime from the same place. Significant differences were reported within the comparison of the length of ruminal papillae between groups $\mathrm{B}$ and $\mathrm{C}(P=0.026)$ and $\mathrm{B}$ and $\mathrm{D}(P=0.040)$, within the comparison of the width of ruminal papillae between groups $\mathrm{A}$ and $\mathrm{D}(P=0.020)$ and within the comparison of the intensity of keratinisation of the mucosa of ruminal papillae between groups $\mathrm{A}$ and $\mathrm{B}(P=0.034), \mathrm{A}$ and $\mathrm{C}(P=0.038)$ and $\mathrm{A}$ and $\mathrm{D}(P=0.001)$. Histopathological and morphometric examination of ruminal mucosa indicated that the ruminal papillae of kids supplemented with zinc in the form of $\mathrm{ZnO}$ (group B) were better developed compared to the other groups. This result indicates better utilisation of the supplemented zinc in the form of $\mathrm{ZnO}$.
\end{abstract}

Forestomach, histometry, inorganic zinc, organic zinc, ruminants

The ruminal mucosa consists of multilayer squamous epithelium with significant keratinisation. The lining has papillae of tongue-like shape on the surface, the height of which is $3-13 \mathrm{~mm}$ and width is $1-3 \mathrm{~mm}$, and these significantly increase the surface of the ruminal epithelium (Hofmann and Schnorr 1982; König et al. 2004; Frappier 2006). The morphological properties of the gut lining including the size of ruminal papillae and their quantity are variable. It is characterised by a process of continual changes, from regression to proliferation. The pathogenesis of morphological adaptation of the ruminal mucosa depends on several factors (Zitnan et al. 2003; Amaral et al. 2005; Černík et al. 2011), including the effect of microelements. This includes cobalt, selenium, copper and also zinc (Arelovich et al. 2008; Eryavuz et al. 2009; Falhar et al. 2009).

Zinc is a component part of various enzymes, nucleic acids, porphyrins, amino acids and proteins. As a stabiliser of cell membranes it ensures among other things also keratinisation of the surface layers of skin and some mucosal membranes, e.g. the oesophagus and rumen (Underwood and Suttle 1999; Sun et al. 2005). Zinc with other trace elements is added to feed mixtures for ruminants and pigs in order to stimulate growth and ensure good health condition and efficiency. It is supplemented in

Address for correspondence:

MVDr. Julius Černík, Ph.D.

Department of Pathological Morphology and Parasitology

Faculty of Veterinary Medicine

University of Veterinary and Pharmaceutical Sciences Brno

Palackého tř. 1- 3, 61242 Brno, Czech Republic

Phone: + 420541562248

E-mail: cernikj@vfu.cz

http://actavet.vfu.cz/ 
various inorganically and organically bound forms; in veterinary and human medicine it is also used for its antibacterial effect (Puchala et al. 1999; Wright et al. 2008; Pechová et al. 2006, 2009; Screenivasan et al. 2009). There is absence of literature describing the effects of oral supplementation of different forms of zinc on ruminal mucosa of kids.

The aim of the study was to identify the effect of supplementation of various forms of zinc on the ruminal mucosa and dimensions of ruminal papillae, to assess the intensity of keratinisation of papillary epithelium in 6-month-old kids, and to compare the obtained results. Our hypothesis was that ruminal papillae would develop more intensively in the group of kids supplemented by inorganic zinc.

\section{Materials and Methods}

The experiment took place in accredited stables of the Ruminant and Swine Clinic of the University of Veterinary and Pharmaceutical Sciences Brno, project number MSM6215712403, approved by the ethics committee. In total 20 kids (10 males and 10 females) of the White Shorthaired Goat breed were divided into four groups of five animals. The experiment lasted 4 months: from the weaning at the age of 2 months until the slaughter at the age of 6 months. All kids were fed the same feeding dose including hay (ad libitum) and granulated feeding mixture (barley $20 \%$, oats $20 \%$, corn $10 \%$, malt sprouts $10 \%$, wheat grit $10 \%$, wheat feeding flour $10 \%$, soy extracted grit $10 \%$, lucern powder $7.5 \%$, dicalcium phosphate $1.5 \%$, sodium chloride $0.6 \%$, calcium carbonate $0.4 \%$ ) at a dose of $300 \mathrm{~g} / \mathrm{animal} /$ day, which was different in the content and form of added zinc. The natural content of zinc in the dry matter of the feeding dose for the kids of control group A (not supplemented with zinc, $n=5$ ) was $40 \mathrm{mg} / \mathrm{kg}$. The granulated feeding mixture of the experimental groups was enriched with various forms of zinc so that the total amount of zinc in the dry matter of the feeding dose was $60 \mathrm{mg}$ of zinc/ $\mathrm{kg}$ of dry matter. Group $\mathrm{B}(\mathrm{n}=5)$ received a feeding mixture enriched with zinc in the form of $\mathrm{ZnO}$, group $\mathrm{C}(\mathrm{n}=5)$ in the form of zinc chelate (Bioplex Zn, Alltech, USA) and group D $(n=5)$ in the form of zinc lactate (trihydrate of zinc lactate, Agrobac, Czech Republic).

The kids were slaughtered by the standard way in abattoir and their organs were subjected to veterinary and hygienic examinations and morphological assessment. Samples for histopathological and morphometric examination were collected after the slaughter of the animals from the rumen, from the bottom of saccus ruminis ventralis every time from the same place in all animals. The size of samples was approximately $1 \times 1 \times 0.5 \mathrm{~cm}$. After collection the tissue was fixed for a period of $72 \mathrm{~h}$ in $10 \%$ formalin. Afterwards, the samples were processed using the common paraffin method, stained with haematoxylin-eosin (Clark 1981) and evaluated by a light microscope. The histological mounts of the rumen tissue were furthermore morphometrically examined by image analysis using Soft Imaging System Cell F (Imaging Software for Life Science Microscopy, OLYMPUS Soft Imaging Solutions). Five variables were measured in three papillae in each section (15 measures per section): the length of the papilla, the width of the papilla, the width of the epithelium, the width of stratum corneum and also keratinisation on the surface of the papillae (Knott et al. 2004; Černík et al. 2011).

Statistical data for morphometry (average values of measurement and standard deviation) were obtained along with the measurements done using the aforementioned computer programme. Measured values were also processed with statistical software XL STAT 2009, version 5.01. The first phase used two sample $t$-test and all 15 values for the group and the measured diameter were compared in order to determine whether the results of the measurement in one group are significantly different from the results of the measurements in the second group (with the significance level of $P \leq 0.05$ ). In the second phase the samples were evaluated using non-parametric Kruskall-Wallis test.

\section{Results}

No pathomorphological changes were observed during the macroscopic inspection of the ruminal mucosa in all groups of kids. During the microscope inspection of the rumen in control group A we found the following changes in the ruminal mucosa: long narrow ruminal papillae, a moderate keratinisation and no pathological changes. In experimental group B we found short massive papillae and moderate keratinisation (lower degree than in group A) and no pathological changes. In experimental groups $\mathrm{C}$ and $\mathrm{D}$ we found long papillae and severe keratinisation and no pathological changes. Detailed morphometric values are given in Table 1. Significant differences obtained with $t$-test and Kruskall-Wallis test are given in Table 2. 
Table 1. Comparison of mean measurements of the ruminal mucosa of goat kids in different groups fed a diet containing different forms of zinc.

\begin{tabular}{lcccc}
\hline Group & A & B & C & D \\
\hline Length of papillae $(\mu \mathrm{m})$ & $1506.14 \pm 508.38$ & $1252.10 \pm 368.17$ & $1703.71 \pm 647.61$ & $1671.30 \pm 658.57$ \\
Width of papillae $(\mu \mathrm{m})$ & $524.73 \pm 112.33$ & $617.05 \pm 155.84$ & $592.99 \pm 206.08$ & $577.69 \pm 242.98$ \\
Width of epithelium $(\mu \mathrm{m})$ & $58.42 \pm 19.94$ & $54.20 \pm 24.20$ & $59.20 \pm 23.21$ & $58.37 \pm 19.48$ \\
Width of stratum & & & & \\
$\quad$ corneum $(\mu \mathrm{m})$ & $12.55 \pm 2.99$ & $18.85 \pm 10.57$ & $23.68 \pm 19.64$ & $20.35 \pm 8.17$ \\
Keratinisation $(\mu \mathrm{m})$ & $15.00 \pm 5.66$ & $16.34 \pm 9.85$ & $26.06 \pm 15.15$ & $26.46 \pm 17.12$ \\
\hline
\end{tabular}

A - control group of goat kids not supplemented with zinc, B - experimental group of goat kids supplemented with $\mathrm{ZnO}, \mathrm{C}$ - experimental group of goat kids supplemented with zinc chelate, D - experimental group of goat kids supplemented with zinc lactate. Data in Table 1 are presented as mean \pm standard deviation. All variables measured 15 times.

Table 2. Significant differences of measurements of the ruminal mucosa of goat kids in different groups fed a diet containing different forms of zinc.

\begin{tabular}{lcc}
\hline Variable & $t$-test & $\begin{array}{c}\text { Kruskall-Wallis test } \\
\text { (A and B and C and D) }\end{array}$ \\
\hline Length of papillae & B and C: $P=0.026$ & $P=0.049$ \\
Bidth of papillae & B and D: $P=0.040$ & \\
A and D: $P=0.020$ & $P=0.050$ \\
Keratinisation & A and B: $P=0.034$ & $P=0.021$ \\
& A and C: $P=0.038$ & \\
\hline
\end{tabular}

A - control group of goat kids not supplemented with zinc, B - experimental group of goat kids supplemented with $\mathrm{ZnO}, \mathrm{C}$ - experimental group of goat kids supplemented with zinc chelate, D - experimental group of goat kids supplemented with zinc lactate. $P$ - significant difference.

\section{Discussion}

Length and width of papillae detected in this study were within physiological range (Hofmann and Schnorr 1982; Jelínek 1995; König et al. 2004). However, as other obtained measures were variable and depended on many factors, no standard physiological values were found for them. Therefore these measures were compared with the same indicators measured in the control group.

Supplementation of organic zinc in a lactate or chelate form has a consequence of larger growth of papillae, thickening of the epithelium and stratum corneum, and also a greater level of keratinisation. Supplementation of inorganic zinc in the form of $\mathrm{ZnO}$ had a consequence of mild widening of papillae and low keratinisation. The aforementioned indicates that morpohologically, supplementation with inorganic zinc was more appropriate. The length and width of papillae is within the normal range (Hofmann and Schnorr 1982; Jelínek 1995) although they possibly do not exceed the length of the control or another trial group. Comparison of group B with control group A determined weaker keratinisation, which provides a possible prerequisite for better utilisation of supplemented zinc in the form of $\mathrm{ZnO}$. In both groups supplemented with organically bound zinc a significant growth of papillae was determined, but also a high level of keratinisation. This would indicate lower utilisation of supplemented zinc in the organic form. This statement may also be 
supported by the results of another part of the same experiment, when it was demonstrated based on the determination of zinc concentrations in the organs (liver, kidney, pancreas, neck muscles) that zinc was most effectively utilised in the form of $\mathrm{ZnO}$, a slightly poorer utilisation was determined in the group receiving $\mathrm{Zn}$ chelate, while the group receiving $\mathrm{Zn}$ lactate did not show an increase of zinc concentration in any of the monitored tissues (Jokverová et al. 2009). Similar results were reported also by other authors (Puchala et al. 1999; Zitnan et al. 2003; Arelovich et al. 2008; Wright et al. 2008).

When there is insufficient supplementation of zinc, disorders of the motility of the forestomachs and subsequent disorders of digestion occur. The resulting morphological changes are manifested as hyperkeratosis and parakeratosis of the epithelium in the ruminal mucosa. The result of hyperkeratotic changes may even be necrosis of the ruminal papillae and inflammation of the lining - rumenitis (Radostits 2007).

The results of this work confirm our hypothesis. Histopathological and morphometric examination of the ruminal mucosa indicated that ruminal papillae of kids from group $\mathrm{B}$ were better developed compared to the other groups. This result indicates better utilisation of the supplemented zinc in the form of $\mathrm{ZnO}$. Conclusive results of morphometric analysis prove the facility of the use of morphometrics as a method useful for veterinary pathology, mainly for the accuracy of histopathological or histological diagnosis.

\section{Acknowledgements}

We would like to thank Mrs. Ana Alačková and Markéta Lišková (University of Veterinary and Pharmaceutical Sciences Brno, Czech Republic) for the processing of the histopathological samples. The study was supported by the Ministry of Education, Youth and Sports of the Czech Republic (Grant No. MSM6215712403).

\section{References}

Amaral CMC, Sugohara A, Resende KT, Machado MRF, Cruz C 2005: Performance and ruminal morphologic characteristics of Saanen kids fed ground, pelleted or extruded total ration. Small Ruminant Res 58: 47-54

Arelovich HM, Laborde HE, Amela MI, Torrea MB, Martinez MF 2008: Effects of dietary addition of zinc and monensin on performance, rumen fermentation and digesta kinetics in beef cattle. Span J Agric Res 6: 362-372

Clark G 1981: General Methods. In: Clark G (Ed.): Staining procedures. Wiliams+Wilkins, Baltimore, USA, pp. 23-25, 36-37

Černík J, Štercová E, Šterc J, Fictum P, Luňáček J, Halouzka R 2011: The effect of intensive fattening of bulls with a high-concentrate diet on ruminal mucosa-a morphometric study. Acta Vet Brno 80: 275-279

Eryavuz A, Dehority BA, Burk A 2009: Effects of supplemental zinc concentration in cellulose digestion and cellulolytic and total bacterial numbers in vitro. Anim Feed Sci Tech 151: 175-183

Falhar J, Pavlata L, Pechová A, Dvořák R 2009: The effect of selenium on selected parameters of ruminal fluid and biomass in cattle and sheep. Folia Vet 53 (Suppl.2): 244

Frappier BL 2006: Digestive system. In: Eurell J, Frappier BL (Eds): Dellmans textbook of veterinary histology. Blackwell Publishing, pp.189-194

Hofmann RR, Schnorr B 1982: The functional morphology of proventriculi. Ferdinand Enke Verlag, Stuttgart, $170 \mathrm{p}$.

Jelínek K 1995: Development dynamics of caprine forestomach in the postnatal period. Acta Vet Brno 64: 49-61

Jokverová O, Pechová A, Mišurová L, Pavlata L, Dvořák R 2009: Effect of Zn supplementation in organic and inorganic form on the concentration in organs and tissues. Folia Vet 53 (Suppl.2): 260

Knott KK, Barboza PS, Bowyer RT, Blake JE 2004: Nutritional development of feeding strategies in arctic ruminants: digestive morphometry of reindeer and muskoxen. Zoology 107: 315-333

König HE, Sautet J, Liebich HG 2004: Digestive system. In: König HE, Liebich HG (Eds): Veterinary anatomy of domestical animals. Shattaver GmbH Stuttgart, pp. 311-315

Pechová A, Pavlata L, Lokajová E 2006: Zinc supplementation and somatic cell count in milk dairy cows. Acta Vet Brno 75: 355-361

Pechová A, Mišurová L, Pavlata L, Dvořák R 2009: The influence of supplementation of different forms of zinc in goats on the zinc concentration in blood plasma and milk. Biol Trace Elem Res 132:112-121

Puchala R, Sahlu T, Davis JJ 1999: Effects of zinc-methionine on performance of Angora goats. Small Ruminant Res 33: 1-8

Radostits OM, Gay CG, Hinchcliff PD, Constable PD 2007: Diseases of the alimentary tract. In: Radostits OM, Done P, Stanley H (Eds): Veterinary medicine: a textbook of the diseases of cattle, sheep, pigs and goats. Elsevier Saunders, Edinburgh, pp. 293-352 
Screenivasan PK, Furgang D, Markowitz K, Mckiernan M, Tischio- Bereski D, Devizio W, Fine D 2009: Clinical anti-microbial efficacy of a new zinc citrate dentifrice. Clin Oral Invest 13: 195-202

Sun JY, Jing MY, Weng XY, Fu LJ, Xu ZR, Zi NT, Wang JF 2005: Effects of dietary zinc levels on the activities of enzymes, weights of organs and the concentration of zinc and copper in growing rats. Biol Trace Elem Res 107: 153-165

Underwood EJ, Suttle NF 1999: Zinc. In: Underwood EJ, Suttle NF (Eds): The mineral nutrition of livestock. CABI Publisching Cambridge, pp. 455-512

Wright CL, Spears JW, Webb KE 2008: Uptake of zinc from zinc sulfate and zinc proteinate by ovine ruminal and omasal epithelia. J Anim Sci 86: 1357-1363

Zitnan R, Kuhla S, Nurnberg K, Schonhuse U, Ceresnakova Z, Sommer A, Baran M, Greserova G, Voigt J 2003 : Influence of diet on the morphology of ruminal and intestinal mucosa and on intestinal carbohydrase levels in cattle. Vet-Med Czech 48: 177-182 